\title{
The results of fetal echocardiography in a tertiary center and comparison of low- and high-risk pregnancies for fetal congenital heart defects
}

\author{
Üçüncü basamak bir merkezde fetal ekokardiyografi sonuçları ve fetal konjenital kalp \\ hastalıkları için düşük ve yüksek risk gruplarının karşılaştırılması
}

\section{Süheyla Özkutlu, Tülay Akça, Gülden Kafalı, Sinan Beksaç}

Department of Pediatric Cardiology, School of Medicine Hacettepe University, Ankara, Turkey

Objective: Fetal echocardiography (FE) is considered for fetal, maternal or hereditary reasons in pregnants with suspect of intrauterine heart disease (IUHD). However, in few studies it was reported that most of the fetuses with IUHD are in the low-risk group (suspicion of IUHD during $2^{\text {nd }}$ trimester ultrasound, lack of good vision of the heart, self-referral). Our aim is to examine retrospectively the reasons for referral of pregnants, the results of $\mathrm{FE}$, distribution of pregnants having fetuses with IUHD according to low- and high- risk factors and to evaluate reliability of FE.

Methods: Our study group consisted of 1395 fetuses and 1370 pregnants underwent FE between 1999 and 2006. These cases included selfreferred women and the pregnants having previous child or family history of cardiac anomaly or referred by obstetricians. The prevalence of IUHDs in low- and high- risk pregnancies was compared by Chi-Square test.

Results: The low risk group included 453 patients and the remaining 917 women were in the high- risk group. Intrauterine heart diseases were detected in $152(10.9 \%)$ of 1395 fetuses. The prevalence of IUHDs was $19 \%$ in the low- risk group and $7 \%$ in the high-risk group. 0 f the 152 fetuses $56.6 \%$ were in the low-risk group and $43.4 \%$ were in the high- risk group. The sensitivity of FE for diagnose of IUHDs was $97 \%$, the specificity was $100 \%$.

Conclusion: Fetal echocardiography is highly reliable method for diagnosing of IUHDs. The most IUHDs occur in the low- risk group.

(Anadolu Kardiyol Derg 2010; 10: 263-9)

Key words: Fetal echocardiography, congenital heart disease, indication, low-risk and high- risk factors

Amaç: Fetal, maternal ve herediter nedenlerle FE yapılan gebeler, konjenital kalp hastalıkı (KKH) fetusa sahip olma olasılığı yüksek olan gebelerdir. Ancak yapılan çok az sayıdaki çalışmada KKH'lı fetusların çoğunun düşük riskli (ikinci trimester ultrasonunda KKH şüphesi, kalbin iyi görüntülenememesi, gebelerin kendi istediğiyle başvurması) gebelik grubuna dahil olduğu bildirilmiştir. Bu çalışmada bölümümüzde son yıllarda FE'si yapılan gebelerin başvuru nedenlerini, ekokardiyografi sonuçlarını ve fetuslarında KKH'ı olan gebelerin düşük ve yüksek risk faktörlerine göre dağılımlarını ve FE sonuçlarımızın güvenilirliğini retrospektif olarak değerlendirdik.

Yöntemler: Çalışmamızda Ekim 1999-Haziran 2006 tarihleri arasında Ünitemizde 1536 gebeye FE yapıldı. Postnatal ekokardiyografi sonucu bilinen 1243 normal kalp bulguları olan fetus ile postnatal ekokardiyografisi ve/veya otopsisi bilinen 152 intrauterin kalp hastalıklı (IUKH) fetus olmak üzere toplam 1395 fetus ve 1370 gebe çalışma grubumuzu oluşturdu. Bu olgular, kadın hastalıkları ve doğum uzmanları tarafından yönlendirilen, kendi isteğiyle başvuran ve ailesinde veya daha önceki gebeliklerinde KKH'ğı olan gebelerden oluşmaktadır. Düşük ve yüksek riskli gebelerdeki IUKH'ğı prevalansı Ki-Kare testiyle karşılaştırılmıştır.

Bulgular: Düşük risk grubunda 453 (\%33.1), yüksek risk grubunda 917 (\%66.9) gebe yer almaktaydı. 1395 fetusun 152'sinde (\%10.9) IUKH saptandı. IUKH sıklığı düşük riskli gebeliklerde \%19, yüksek riskli gebeliklerde \%7 idi. 152 fetusun \%56.6'sı düşük risk, \%43.4'ü yüksek risk grubuna dahil gebeliklerde yer alıyordu. IUKH'lı fetusların \%54.6'sındaki başvuru nedeni düşük risk grubundaki ikinci trimester ultrasonunda KKH'ğı şüphesi idi. IUKH'larının tanısındaki duyarlılığımız \%97, özgüllüğümüz \%100 idi.

Sonuç: IUKH'larının tanısında FE çok güvenilir bir yöntemdir. KKH'nın büyük bir kısmı düşük risk gurubuna dahil gebeliklerde yer almaktadır. (Anadolu Kardiyol Derg 2010; 10: 263-9)

Anahtar kelimeler: Fetal ekokardiyografi, konjenital kalp hastalığı, endikasyon, düşük risk ve yüksek risk faktörleri 


\section{Introduction}

Congenital heart diseases (CHD) are the most common cardiac malformations with high mortality and morbidity $(1,2)$. The progress in ultrasound imaging technology provides significant improvement for prenatal diagnose of intrauterine heart diseases (IUHDs) (3-6). Fetal echocardiography (FE) is a method, which takes long time, requires high skilled and experienced investigators and is costly. There is no chance to perform FE to all pregnants in developing countries. Fetal echocardiography is performed in a few pediatric centers in our country. As a result of this, it is very important to define the pregnants who need FE and the centers performed FE.

The pregnants who undergo FE by fetal, maternal and hereditary reasons are at high risk for having a fetus with $\mathrm{CHD}$. However, it has been reported that most of the fetuses with CHD are in the low risk group (suspicion of CHD during $2^{\text {nd }}$ trimester ultrasound, lack of good vision of the heart, self referral) in few studies in which the mothers having the fetus or child with CHD were evaluated $(7,8)$.

In this study, we evaluated reasons for referral of the pregnants who underwent $F E$, the results of $F E$ and categorized the pregnants having the fetus with CHD according to high- and low-risk groups by reason for referral.

\section{Methods}

\section{Study patients}

The patients in our study consist of the pregnants referred by obstetricians, having previous child or family history of cardiac anomaly and who are self-referral. We recorded the ages and referral reasons of the patients, referring hospitals, number and properties of previous pregnancies, used medicines, whether or not pregnants or their partners have experienced any diseases, if there are any other organ anomalies of fetus, chromosomal disorders, findings of other pregnancies and heart findings of them. In our study, all these data were retrospectively examined.

\section{Fetal echocardiography}

Fetal echocardiography was made by the same doctor and a Trinitron GE Vivid Five performance echocardiographic scanner with 2.5-5 MHz transducers (Cardiovascular Ultrasound Systems, General Electric, Horten, Norway). The fetal examination included the standard techniques to evaluate the position and axis of the heart and for scanning plans and conventional Doppler and M-mode measurements $(9,10)$. The structural disorders of the heart were evaluated by a two-dimensional ultrasound imaging technique and rhythm and dimensions of heart by M-mode technique were evaluated. Echocardiography procedure was repeated several times to pregnants having unclear ultrasound imaging, dysrhythmia, fetuses with CHD and those with polypregnancies.

\section{Outcome}

We suggested all pregnants with normal FE to come again for postnatal echocardiographic control or if it is not possible to inform us when they are evaluated postnatally by any pediatric cardiologist and instruct us about of result. Also, we recommended to the pregnants having fetuses with $\mathrm{CHD}$ to deliver in our center. Cases whose postnatal echocardiographic findings and/or the autopsy results could not be obtained were not included in this study.

We told to the parents that pregnancies of the pregnants younger than 24 weeks old with complex CHD might be terminated (6). If the parents with complex cardiac anomaly do not want to terminate the pregnancy with complex cardiac anomaly or if the fetus is older than 24 weeks or has cardiac anomaly other than complex CHD, we informed the parents about the centers performing medical and surgical treatment of CHDs. The postmortem results of cases whose pregnancies were terminated were recorded.

\section{Statistical analysis}

The pregnants referred by several reasons were grouped according to basic reason. The percentages for describing numbers of the pregnants were calculated (6-8). All statistical analyses were done using SPSS for Windows Version 17.0 software (Chicago, IL, USA). The prevalence of IUHDs in low- and highrisk pregnancies was compared using the Chi-square test. Statistical significance was inferred at $\mathrm{P}<0.05$. Reliability of $\mathrm{FE}$ was evaluated by sensibility and specificity formulas.

\section{Results}

Between October 1999 and June 2006, 1536 pregnants underwent FE. Because the results of postnatal echocardiography of 146 fetuses with normal heart and 20 fetuses with CHD were not obtained they were excluded from the study. Twenty-five of the remaining 1370 pregnants were polypregnancies (3 of them had structural CHD). Thus, our study group consisted of 1395 fetuses (1243 fetuses with normal heart, 152 fetuses with IUHD). The results of postnatal echocardiography and/or reports of fetal and natal autopsies of all the patients were obtained.

Of 152 fetuses with IUHD, 144 had structural CHD, 5 had "noncompaction" of left ventricle and 3 had rhabdomyoma.

The referral reasons of the pregnants underwent FE were shown in Table 1. The most common referral reason was history of fetus or child with a cardiac anomaly in previous pregnancy or pregnancies. Most of these pregnants were mothers of children followed upin our unit. Second frequent referral reason was diagnose or suspicion of CHD during $2^{\text {nd }}$ trimester ultrasound performed by obstetricians. Most of these pregnants were referred from the of obstetrics and gynecology clinic of our hospital. Self-referral pregnants were health professionals.

Intrauterine heart diseases were determined in $152(10.9 \%)$ of 1370 fetuses belong to 1395 pregnants. Prevalence of IUHD according to referral reasons, is shown in Table 1. Of IUHDs, $94.7 \%$ $(n=144)$ had structural CHDs and $5.3 \%(n=8)$ had other diagnosis ("noncompaction" of left ventricle and rhabdomyoma).

When the pregnants were classified according to low- and high-risk factors, $453(33.07 \%)$ pregnants were in low-risk group 
Table 1. Referral reasons of pregnants and prevalence of intrauterine heart diseases

\begin{tabular}{|c|c|c|c|c|}
\hline Referral reason & $\mathbf{n}$ & $\%$ & IUHD, n & $\%$ \\
\hline Previous child or fetus with CHD & 274 & 20.00 & 13 & 4.7 \\
\hline Suspicion or diagnosis of CHD during $2^{\text {nd }}$ trimester ultrasound & 256 & 18.69 & 83 & 32.4 \\
\hline Self referral & 193 & 14.09 & 3 & 1.6 \\
\hline Maternal metabolic disease (diabetes mellitus, homocysteinemia) & 127 & 9.27 & 9 & 7 \\
\hline Fetal dysrhythmia & 75 & 5.47 & 13 & 17.3 \\
\hline Advanced maternal age & 71 & 5.18 & 2 & 2.8 \\
\hline Bad obstetric history & 56 & 4.09 & 2 & 3.5 \\
\hline Polyhydramniosis, oligohydramniosis, IUGR & 43 & 3.14 & 1 & 2.3 \\
\hline Maternal another diseases & 32 & 2.34 & - & \\
\hline Previous child with other cardiac anomaly than $\mathrm{CHD}$ & 29 & 2.12 & - & \\
\hline Non immune hydrops & 26 & 1.90 & 5 & 19.2 \\
\hline Fetal anomaly & 25 & 1.82 & 6 & 24 \\
\hline Previous child with other anomalies than heart & 25 & 1.82 & 2 & 8 \\
\hline Poly pregnancy & 25 & 1.82 & 3 & 12 \\
\hline Previous child with the other diseases (PKU, immune deficiency) & 22 & 1.61 & - & \\
\hline Maternal using of medicine & 21 & 1.53 & - & \\
\hline Maternal CHD & 16 & 1.17 & 4 & 25 \\
\hline Fetal chromosomal anomaly & 10 & 0.73 & 2 & 20 \\
\hline Paternal CHD & 7 & 0.51 & 2 & 28.5 \\
\hline Immune hydrops & 7 & 0.51 & - & \\
\hline Maternal SLE or Sjögren disease (presence of autoantibody) & 7 & 0.51 & - & \\
\hline Single umbilical artery & 4 & 0.29 & 1 & 25 \\
\hline Lack of good vision of the heart during $2^{\text {nd }}$ trimester ultrasound & 4 & 0.29 & - & \\
\hline Increased nuchal translucency & 3 & 0.22 & - & \\
\hline Rubella antibody positivity & 2 & 0.15 & - & \\
\hline Familial history of CHD (out of parents and sibling) & 2 & 0.15 & 1 & 50 \\
\hline Unknown reason & 8 & $0.58)$ & - & \\
\hline TOTAL & 1370 & 100.00 & 152 & \\
\hline
\end{tabular}

and 917 (66.93\%) of them were in high-risk group (Table 2). The low-risk group included 256 pregnants having suspicion of CHD during $2^{\text {nd }}$ trimester ultrasound and 4 cases having lack of good vision of the heart. Overall 193 women were self-referred. The majority of high-risk group included pregnants having hereditary risk factors $(n=415)$.

The distribution and prevalence of main cardiac anomalies of 144 pregnants with structural CHD are shown in Table 3. The most frequent structural CHDs were ventricular septal defect (VSD) (16.7\%), atrioventricular septal defect (AVSD) (13.9\%), hypoplastic left heart syndrome $(11 \%)$, double-outlet right ventricle (DORV) $(9 \%)$ and the malformations having univentricle morphology $(7.6 \%)$.

There were 8 cases with no structural CHDs, 5 of them had"noncompaction" of left ventricle and 3 had rhabdomyoma. Three patients with "noncompaction" were diagnosed prenatally and the other 2 cases postnatally (11). The diagnosis of 3 cases with "noncompaction" and 2 - with rhabdomyoma were confirmed with postnatal echocardiography. As a result, total number of IUHDs was 152 and the number of postnatal echocardiography was 116 . Of IUHDs, $3.3 \%$ were cases with diagnosis of "noncompaction" and 1.9\% - rhabdomyoma.

When we categorized the structural CHDs according to severity, $57 \%(n=82)$ of cases were defined as complex, $35.4 \%$ $(n=51)$-as significant and $7.6 \%(n=11)$-as having minor cardiac anomalies (Table 4).

Thirty-six pregnancies in complex group and younger than 24 weeks were terminated by parents' acceptance (Table 3). Postnatal echocardiography was performed in 108 cases. Five of these patients (1 with AVSD, 1 -hypoplastic left heart syndrome, 1-critical AS, 2- the critical CoAs) died in neonatal stage despite surgical interventions or angioplasty procedures were made. The autopsy results of these patients were recorded.

Echogenic focus was detected in 17 fetuses with normal heart (15- left ventricle, 2-right ventricle). Of 2 fetuses consid- 
Table 2. Distribution of pregnants according to low and high risk factors

\begin{tabular}{|c|c|c|}
\hline Risk factors & $\mathbf{n}$ & $\%$ \\
\hline \multicolumn{3}{|l|}{ Low risk } \\
\hline Suspicion of CHD during 2nd trimester ultrasound & 256 & 18.69 \\
\hline Self referral & 193 & 14.09 \\
\hline Lack of good vision of the heart by ultrasound & 4 & 0.29 \\
\hline Total & 453 & 33.07 \\
\hline \multicolumn{3}{|l|}{ High risk } \\
\hline Maternal factors & 276 & 20.15 \\
\hline Maternal metabolic disease & 127 & 9.27 \\
\hline Advanced maternal age & 71 & 5.18 \\
\hline Maternal the other diseases & 32 & 2.34 \\
\hline Maternal using of medicine & 21 & 1.53 \\
\hline Maternal CHD & 16 & 1.17 \\
\hline Maternal autoantibody positivity (SLE, Sjögren disease) & 7 & 0.51 \\
\hline Rubella antibody positivity & 2 & 0.15 \\
\hline Fetal factors & 218 & 15.90 \\
\hline Dysrhythmia & 75 & 5.47 \\
\hline Polyhydramniosis, oligohydramniosis, IUGR & 43 & 3.14 \\
\hline Non immune hydrops & 26 & 1.90 \\
\hline Fetal anomaly & 25 & 1.82 \\
\hline Poly pregnancy & 25 & 1.82 \\
\hline Chromosomal anomaly & 10 & 0.73 \\
\hline Immune hydrops & 7 & 0.51 \\
\hline Single umbilical artery & 4 & 0.29 \\
\hline Increased nuchal translucency & 3 & 0.22 \\
\hline Hereditary factors & 415 & 30.30 \\
\hline Previous child or fetus with $\mathrm{CHD}$ & 274 & 20.00 \\
\hline Poor obstetric history & 56 & 4.09 \\
\hline Previous child with other cardiac anomaly than CHD & 29 & 2.12 \\
\hline Previous child with other anomalies than heart & 25 & 1.82 \\
\hline $\begin{array}{l}\text { Previous child with the other diseases (FKU, immune } \\
\text { deficiency, etc) }\end{array}$ & 22 & 1.61 \\
\hline Paternal CHD & 7 & 0.51 \\
\hline Familial CHD (out of parents and sibling) & 2 & 0.15 \\
\hline Unknown reason & 8 & 0.58 \\
\hline TOTAL & 917 & 66.93 \\
\hline GENERAL TOTAL & 1370 & 100.00 \\
\hline
\end{tabular}

CHD - congenital heart disease, IUGR- intrauterine growth retardation, PKU- phenylketonuria, SLE- systemic lupus erythematosus

ered as having normal heart, one had intermediate type of AVSD (small primum type of ASD and small inlet type of VSD) and the other had tetralogy of Fallot (TOF) postnatally. In addition, one case with prenatal VSD that was closed spontaneously and one case with sustained sinus bradycardia and heart failure prenatally were diagnosed as "noncompaction" (12).
Prenatal diagnoses of these cases, were in agreement with postnatal and autopsy diagnoses. Sensitivity of FE was $97 \%$ and specificity was $100 \%$ in our study.

Eighty-six (56.6\%) of 152 fetuses with IUHD were in low- risk pregnancies, $66(43.4 \%)$ were in high-risk pregnancies. The prevalence of IUHD was $86(19 \%)$ in 453 low- risk pregnants and $66(7.1 \%)$ in 917 high-risk pregnants. The prevalence of IUHDs was significantly higher in low-risk group $(p<0.001)$ (Table 5$)$.

The distribution of IUHD according to referral groups of IUHDs is shown in Table 6: $83(54.6 \%)$ of 152 pregnants having fetuses with IUHD were in the group with suspected CHD's during second trimester ultrasound.

\section{Discussion}

In our study, intrauterine heart diseases were detected in 152 $(10.9 \%)$ of 1395 fetuses. When fetuses with IUHDs were compared according to high- and low-risk pregnancies, we found that IUHD prevalence was $19 \%$ in low risk group, but only $7 \%$ in high-risk group $(\mathrm{p}<0.001)$. Of the 152 fetuses, $56.6 \%$ were in the low-risk group and $43.4 \%$ were in the high-risk group. However, the most frequent referral reason among the pregnants who underwent $\mathrm{FE}$ was history of previous child or fetus with cardiac anomaly in the high-risk group (20\%) The sensitivity of FE for diagnose of IUHDs was $97 \%$, the specificity was $100 \%$.

When the mothers that have a child with structural CHD become pregnant, we inform them that they have a high risk for a child with cardiac anomaly, and also suggest them to be controlled by FE during each pregnancy. Since many years, it has been challenging issue whether the pregnants would like to know if they have a fetus with cardiac anomaly. Our finding of high prevalence of pregnants who had fetusus with CHD in their previous pregnancies shows women who are faced with this disease with high mortality and morbidity prefer to learn 'good or bad' result when they offered good counseling. Also, our finding supports studies that suggest increased sensitivity of mothers about FE (13).

The majority of self-referred pregnants were health professionals from our or other hospitals. These pregnants with high sociocultural level were referred to eliminate their concerns although their cardiac findings during $2^{\text {nd }}$ trimester ultrasound were normal.

We diagnosed IUHD in 152 cases (10.9\%), structural CHD in 144 cases $(10.3 \%)$ by FE. These rates are higher than the levels reported in literature. Todros et al. (7) detected prevalence of $\mathrm{CHD}$ as $4.9 \%$ at 4523 pregnants by FE, and Perri et al. (8) reported prevalence to be as $2.7 \%$ of 1696 pregnants. This variability in prevalence of prenatal $\mathrm{CHD}$ may result from more common FE applications, different health policies or a specific society screening in these countries. The prevalence of IUHD in our study is 2-3 times higher than in the studies mentioned above. Our hospital is a tertiary center with referral of high -risk pregnancies from all over country and this might explain increased number of high-risk pregnancies. Indeed $43.4 \%$ of fetuses with IUHD was born from pregnants with high risk. 
Table 3. The prevalence of structural CHDs and the results of postnatal echocardiography and autopsy

\begin{tabular}{|c|c|c|c|c|c|}
\hline Results of fetal echocardiography & $\mathbf{n}$ & $\%$ & $\begin{array}{c}\text { Postnatal } \\
\text { echocardiography, } n\end{array}$ & Autopsy F, n & Autopsy PN, n \\
\hline Ventricular septal defect (VSD) & 24 & 16.7 & 24 & - & \\
\hline Atrioventricular septal defect (AVSD) & 22 & 13.9 & 13 & 9 & 1 \\
\hline Hypoplastic left heart & 16 & 11.1 & 11 & 5 & 1 \\
\hline Double outlet right ventricle (DORV) & 13 & 9.0 & 7 & 6 & - \\
\hline Single ventricle & 11 & 7.6 & 8 & 3 & - \\
\hline Single atrium or large atrial septal defect (ASD) & 10 & 6.9 & 10 & - & - \\
\hline Ebstein anomaly & 9 & 6.3 & 6 & 3 & - \\
\hline D-transposition of great arteries (d-TGA) & 6 & 4.2 & 3 & 3 & - \\
\hline Tetralogy of Fallot (TOF) & 4 & 2.8 & 4 & - & - \\
\hline Aortic stenosis (AS) & 4 & 2.8 & 4 & - & 1 \\
\hline Mitral valvular anomaly & 3 & 2 & 3 & - & - \\
\hline Pulmonary atresia, VSD & 3 & 2 & 2 & 1 & - \\
\hline Coarctation of the aorta (CoA) & 3 & 2 & 3 & - & 2 \\
\hline Pulmonary stenosis (PS) & 3 & 2 & 2 & 1 & - \\
\hline C-transposition of great arteries (c-TGA) & 3 & 2 & 3 & - & - \\
\hline Primum atrial septal defect (primum ASD) & 2 & 1.4 & 2 & - & - \\
\hline Aortic interruption & 2 & 1.4 & - & 2 & - \\
\hline Truncus arteriosus & 2 & 1.4 & 1 & 1 & - \\
\hline Absence of pulmonary artery & 2 & 1.4 & 1 & 1 & - \\
\hline Imperforate pulmonary valve & 1 & 0.7 & 1 & - & - \\
\hline Absence of pulmonary valve & 1 & 0.7 & - & 1 & - \\
\hline TOTAL & 144 & 100 & 108 & 36 & 5 \\
\hline
\end{tabular}

Table 4. Distribution according to severity of structural CHDs

\begin{tabular}{|l|c|c|}
\hline Category & $\mathbf{n}$ & $\%$ \\
\hline Complex & 82 & 57.0 \\
\hline Significant & 51 & 35.4 \\
\hline Minor & 11 & 7.6 \\
\hline Total & 144 & 100.0 \\
\hline CHD - congenital heart disease \\
\hline
\end{tabular}

Table 5. Distribution of IUHDs according to pregnancies with low and high risk factors

\begin{tabular}{|l|c|c|c|c|c|}
\hline \multirow{2}{*}{} & \multicolumn{2}{|c|}{ Pregnant } & \multicolumn{2}{c|}{ IUHD } & Rate of CHDs in risk groups \\
\cline { 2 - 6 } & $\mathbf{n}$ & $\%$ & $\mathbf{n}$ & $\%$ & $\%$ \\
\hline Low- risk group & 453 & 33.1 & 86 & 56.6 & 19.0 \\
\hline High- risk group & 917 & 66.9 & 66 & 43.4 & 7.1 \\
\hline TOTAL & 1370 & 100.0 & 152 & 100.0 & \\
\hline $\begin{array}{l}\text { Chi - square test value: } 42.7, \mathrm{p}<0.001 \\
\text { CHD - congenital heart disease, IUHD - intrauterine heart disease }\end{array}$ \\
\hline
\end{tabular}

IUHD was observed in $32.4 \%$ of pregnants referred by suspicion or diagnosis of CHD during $2^{\text {nd }}$ trimester ultrasound. In Perri's study (7), CHD was detected in $48.7 \%$ of 78 pregnants underwent $\mathrm{FE}$ because of this indication. We can explain this result by difference in imaging techniques used by obstetricians.
Copel et al. (20) advocate that sensitivity of four-chamber view is higher, whereas other authors consider this approach as low sensitive (4-40\%) (14-21). Usually FE studies report that fourchamber view has low sensitivity, obstetric ultrasound studies report high sensitivity. The reported sensitivity of obstetric ultrasound by only four-chamber view was $30-50 \%$. When outflow tracts of aorta and pulmonary artery, three-vessel and trachea view were added to this view sensitivity increased up to $86-99 \%$ $(22,23)$. Our results support the opinion that a standard heart imaging method showing also outflow tracts of main vessels in out-patient obstetric and gynecology clinics must be improved.

In our study, it was shown that $56.6 \%$ of fetuses with IUHD were in low-risk group and $54.6 \%$ of them were pregnants having suspicion or diagnosis of CHD during $2^{\text {nd }}$ trimester ultrasound. In Todros' s study (8), 70\% of fetuses with CHD were in low-risk group and majority them were pregnants having suspicion or diagnosis of CHD during $2^{\text {nd }}$ trimester ultrasound. In Perri's study (7), $89.1 \%$ of 46 fetuses with CHD were from pregnancies in low-risk group, $82.6 \%$ of them have suspicion or diagnosis of CHD during $2^{\text {nd }}$ trimester ultrasound, and $17.4 \%$ of them have lack of good vision of the heart and self- referral. In Perri and Todros' s screening studies $(7,8)$, majority of fetuses with CHD were in low-risk group, and $70-80 \%$ of them were pregnancies having suspicion or diagnosis of CHD. Our rates are lower than reported in these studies because of number of preg- 
Table 6. Distribution of IUHDs according to referral groups

\begin{tabular}{|l|c|c|}
\hline \multirow{2}{*}{ Referral reason } & \multicolumn{2}{|c|}{ CHD } \\
\cline { 2 - 3 } & $\mathbf{n}$ & $\%$ \\
\hline Suspicion of CHD during 2nd $^{\text {trimester ultrasound }}$ & 83 & 54.6 \\
\hline Previous child or fetus with CHD & 13 & 8.6 \\
\hline Fetal dysrhythmia & 13 & 8.6 \\
\hline Maternal metabolic disease (diabetes mellitus, & 9 & 5.9 \\
homocysteinemia) & & \\
\hline Fetal anomaly & 6 & 3.9 \\
\hline Maternal CHD & 4 & 3.3 \\
\hline Polypregnancy & 3 & 2.6 \\
\hline Non immune hydrops & 5 & 2 \\
\hline Self referral & 3 & 2 \\
\hline Paternal CHD & 2 & 1.3 \\
\hline Chromosomal anomaly & 2 & 1.3 \\
\hline Previous child with other anomalies than heart & 2 & 1.3 \\
\hline Bad obstetric history & 2 & 1.3 \\
\hline Advanced maternal age & 2 & 1.3 \\
\hline Single umbilical artery & 1 & 0.7 \\
\hline Familial history of CHD (out of parents and sibling) & 1 & 0.7 \\
\hline Polyhydramniosis, oligohydramniosis, IUGR & 1 & 0.7 \\
\hline TOTAL & 152 & 100.0 \\
\hline
\end{tabular}

CHD - congenital heart disease, IUGR - intrauterine growth retardation, IUHD - intrauterine heart disease

nants in high-risk group is higher. When fetuses with IUHDs were compared according to high-and low-risk pregnancies, we found that IUHD prevalence was $19 \%$ in low risk group, but only $7 \%$ in high- risk group $(\mathrm{p}<0.001)$.

The most frequently observed structural CHDs in our study were VSD, AVSD, hypoplastic left ventricle and DORV. In Hoffman's comprehensive screening study (1), the most frequently observed structural CHD was VSD. Perri et al. (7) reported percentage of TOF as $19.6 \%$, VSD as $17.4 \%$, d-TGA as $17.4 \%$, hypoplastic left heart as $15.2 \%$ and AVSD as $10.9 \%$.

According to recent data, echogenic focus is a not pathologic symptom and is a normal finding of developing heart $(7,24)$. We detected 17 echogenic focus and none of them had any CHD or Down syndrome.

Families in 36 (44\%) of 82 pregnants having fetuses with CHD were opted to terminate the pregnancy. As long as pregnancies are less than 24 weeks, $50-66 \%$ of families having fetuses with complex CHD prefer to terminate the pregnancy $(25,26)$. When we compare diagnosis of the patients with CHD with postnatal echocardiography and autopsy data, specificity of FE in diagnosis of CHDs was $100 \%$ and sensitivity- $97 \%$. These values are better than in our first study and similar to results reported in literature (26-28). When prenatal diagnoses were compared with autopsy and postnatal echocardiography results, specificity rates varied between $70-98 \%$ (26-29).
We think that the reasons of this improvement are due to increased experience of consultant and advancement in transducer engineering.

\section{Conclusion}

Fetal echocardiography is a highly reliable method for diagnosing of IUHDs. Most of the CHDs were determined in pregnancies in low-risk group. Therefore, it should be the mission of gynecologists and obstetricians to determine IUHDs. Pregnant women with a history of previous child with congenital heart defect should be referred for fetal echocardiography.

\section{Conflict of interest: None declared}

\section{References}

1. Hoffman JI. Incidence of congenital heart disease: I. Postnatal incidence. Pediatr Cardiol 1995; 16: 103-13.

2. Allan L, Benacerraf B, Copel JA, Carvalho JS, Chaoui R, Eik-Nes $\mathrm{SH}$, et al. Isolated major congenital heart disease. Ultrasound Obstet Gynecol 2001; 17: 370-9.

3. Özkutlu S, Elshershari H, Akçören Z, Önderoğlu LS, Tekinalp G. Visceroatrial situs solitus with atrioventricular alignment discordance, double outlet right ventricle and superoinferior ventricles: fetal and neonatal echocardiographic findings. J Am Soc Echocardiogr 2002; 15: 749-52.

4. Beksaç MS, Balcı $S$, Güvendağ Güven ES, Güven $S$, Özkutlu $S$. Complex conotruncal cardiac anomalies consecutively in three siblings from a consanguineous family possibly associated with maternal hyperhomocysteinemia. Arch Gynecol Obstet 2007; 276: 547-9.

5. Özkutlu S, Ayabakan C, Demircin M, Yılmaz M. Acase of superoinferior ventricular heart with situs ambiguus, dextroventricular loop, and levo transposition of the arteries: prenatal and postnatal echocardiographic diagnosis. Pediatr Cardiol 2003; 22: 45-51.

6. Özkutlu S, Ayabakan C, Karagöz T, Önderoğlu L, Deren 0, Çağlar M, et al. Prenatal echocardiographic diagnosis of congenital heart disease: comparison of past and current results. Turk $\mathrm{J}$ Pediatr 2005; 47: 232-8.

7. Perri T, Cohen-Sacher B, Hod M, Berant M, Meizner I, Bar J. Risk factors for cardiac malformations detected by fetal echocardiography in a tertiary center. J Matern Fetal Neonatal Med 2005; 17: 123-8.

8. Todros T, Faggiano F, Chiappa E, Gaglioti P, Mitola B, Sciarrone A. Accuracy of routine ultrasonography in screening heart disease prenatally. Prenat Diagn 1997; 17: 901-6.

9. Cordes TM, O' leary PW, Seward JB, Hagler DJ. Distinguishing right from left: a standardized technique for fetal echocardiography. J Am Soc Echocardiogr 1994; 7: 47-53.

10. Drose JA. Scanning: indications and technique. In: Drose JA, editors. Fetal Echocardiography. Phildelphia; W.B. Saunders Company. 1998. p.1-13

11. Özkutlu S, Bostan 0, Karagöz T, Deren 0, Tekinalp G. Prenatal diagnosis of isolated non-compaction of the ventricular myocardium: study of six cases. Pediatr Int 2007; 49: 172-6.

12. Özkutlu S, Önderoğlu L, Karagöz T, Çeliker A, Şahiner UM. Isolated noncompaction of left ventricular myocardium with fetal sustained bradycardia due to sick sinus syndrome. Turk J Pediatr 2006; 48: 383-6.

13. Sklansky M, Sklansky M, Tang A, Levy D, Grossfeld P, Kashani I, et al. Maternal psychological impact of fetal echocardiography. J Am Soc Echocardiogr 2002; 15: 159-66. 
14. Vergani P, Mariani S, Ghidini A, Schiavina R, Cavallone M, Locatelli A. Screening for congenital heart disease with the four-chamber view of the fetal heart. Am J Obstet Gynecol 1992; 167: 1000-3.

15. Hoffman Jl, Christianson R. Congenital heart disease in a cohort of 19502 births with long- term follow-up. Am J Cardiol 1978; 42: 641-7.

16. Bull C. Current and potential impact of fetal diagnosis on prevalence and spectrum of serious congenital heart disease at term in the UK. Lancet 1999; 354: 1242-7.

17. Chow JS, Benson CB, Doubilet PM. Frequency and nature of structural anomalies in fetuses with single umbilical arteries. J Ultrasound Med 1998; 17: 765-8.

18. Tegnander E, Williams W, Johanses OJ, Blaas HGK, Eiknes SH. Prenatal detection of heart defects in a non-selected population of 30149 fetuses-detection rates and outcome. Ultrasound Obstet Gynecol 2006; 27: 252-65.

19. Zosmer N, Souter VL, Chan CS, Huggon IC, Nicolaides KH. Early diagnosis of major congenital cardiac defects in chromosomally normal fetuses with increased nuchal translucency. $\mathrm{Br} \mathrm{J}$ Obstet Gynecol 1999; 106: 829-33.

20. Copel JA, Pilu G, Green J, Hobbins JC, Kleinman CS. Fetal echocardiographic screening for congenital heart disease: The importance of four-chamber view. Am J Obstet Gynecol 1987; 157: 648-55.

21. Buskens E, Grobbee DE, Frohn-Mulder IM, Stewart PA, Juttmann $R E$, Wladimiroff JW, et al. Efficacy of routine fetal ultrasound screening for congenital heart disease in normal pregnancy. Circulation 1996; 94: 67-72.
22. Meyer-Wittkopf M, Cooper S, Sholler G. Correlation between fetal cardiac diagnosis by obstetric and pediatric cardiologist sonographers and comparison with postnatal findings. Ultrasound Obstet Gynecol 2001; 17: 392-7.

23. Del Bianco A, Russo S, Lacerenza N, Rinaldi M, Rinaldi G, Nappi L. Four chamber view plus three-vessel and trachea view for a complete evaluation of the fetal heart during the second trimester. J Perinat Med 2006; 34: 309-12.

24. Didly GA, Judd VE, Clark SL. Prospective evaluation of the antenatal and postnatal significance of the fetal echogenic cardiac focus: a case control study. Am J Obstet Gynecol 1996; 175: 1008-12.

25. Stoll C, Alembik Y, Dott B, Meyer MJ, Pennerath A, Peter M0, et al. Evaluation of prenatal diagnosis of congenital heart disease. Prenat Diagn 1998; 18: 801-7.

26. Fesslova V, Nava S, Villa L. Evolution and long term outcome in cases with fetal diagnosis of congenital heart disease: Italian multicentre study. Fetal Cardiology Study Group of the Italian Society of Pediatric Cardiology. Heart 1999; 82: 594-9.

27. Özkutlu S, Saraçlar M. The accuracy of antenatal fetal echocardiography. Turk J Pediatr 1999; 41: 349-52.

28. Tometzki AJ, Kohl T, Kovalchin JP, Silverman NH. Accuracy of prenatal echocardiographic diagnosis and prognosis of fetuses with conotruncal anomalies. J Am Coll Cardiol 1999; 33: 1696-701.

29. San Luis Miranda R, Arias Monroy LG, Gutiérrez González GA, León Avila JL, Cruz Rodríguez A, Osornio Correa PR. Fetal echocardiography efficiency. Clinical experience. Ginecol Obstet Mex 2008; 76: 706-16. 